\title{
Ilkka Levä
}

\section{Sota Suomesta? Uusi työelämän psykologinen sopimus 1990-luvun laman lehdistöpuheessa}

\section{Tiivistelmä}

Artikkeli tarkastelee työtä koskevan psykologisen sopimuksen muutosta Suomen 1990-luvun lamassa. Analyysi perustuu Gilles Deleuzen ja Félix Guattarin kapitalismiteorialle. Aineistona toimii työmarkkinoihin liittyvä lehdistömateriaali vuosilta 1991-1993, jossa ilmeneviä työmarkkinauskomuksia uudenlaisesta työn psykologisesta sopimuksesta ja sen vaatimasta työelämän ihannesubjektiviteetista tutkitaan kulttuurintutkimuksellisesti. Artikkeli väittää laman olleen lehdissä sodankäyntiä ja poikkeustoimille tilaa avannut kriisi. Työelämä ladattiin välttämättömyyksillä, ja vastuu siirtyi yksilöille, sillä kokonaisuutta ei koettu voitavan muuttaa. Luterilaisen etiikan mukainen uhrautumisen työkulttuuri, pettymys vanhaan kollektiiviseen, kasinotalouden moraaliin ja laman syvyys vahvistivat muutoksen omaksumista. Työtä koskeva psykologinen sopimus muuttui painottamaan työntekijöiden yksilöllistynyttä vastuuta. Syntyneet puhekehykset ovat säilyneet nykypäivään asti, sillä lamaa ei ole Suomessa käsitelty loppuun. 
"Olemme selvästi joutuneet taitekohtaan, jossa jokin vaihe on päättynyt, mutta emme tiedä, mihin olemme menossa: menneisyys ei enää 'suorana ja hämmentymättömänä' virtaa tulevaisuudeksi. Siksi juuri nyt, 76 vuotta Volter Kilven pohdintojen jälkeen, on jälleen kansallisen itsetutkiskelun hetki." (Niiniluoto 1994, 15.)

\section{Johdanto}

Tässä artikkelissa tutkitaan 1990-luvun laman aikaista lehdistön julkista työelämäpuhetta ja kartoitetaan hegemonisen puheen muutosta, jossa suomalaiseen työelämään tuotettiin työtä koskevaa psykologista sopimusta määrittäneet uudenlaiset puheen kehykset ja niistä seuranneet työelämän ihannesubjektiviteetit. Lehdistöpuhe oli poliittisista positioista johtuen täynnä ristiriitaisia mielipiteitä, mutta silti niissä ilmenevät työelämäpuheen muuttuneet vaatimukset.

Analyysia voi kutsua historiallisesti orientoituneeksi kulttuurintutkimukseksi, sillä tutkimusaineistoja luetaan refleksiivisen sisällönanalyysin keinoin (vrt. esim. Salo 2015, 166-187). Analyysi perustuu Gilles Deleuzen ja Félix Guattarin pragmaattiseen kieliteoriaan (1980, 95-139), jossa otetaan huomioon tarkastellun yhteiskunnan historiallinen konteksti ja puheen valtaulottuvuudet.

Tarkasteltavina ovat vuosilta 1991-1993 valtakunnallisesti merkittävimmät sanomalehdet sekä sellaiset paikallislehdet, joissa puhuttiin lamasta työelämän muutoskontekstissa (aakkosjärjestyksessä): Aamulehti (AL), Etelä-Saimaa (ES), Etelä-Suomen Sanomat (ESS), Helsingin Sanomat (HS), Ilkka (I), Iltalehti (IL), Keskisuomalainen (KSML), Länsi-Savo (LS), Pohjalainen (P), Pohjolan Sanomat (PoS), Raahelainen (R), Satakunnan Kansa (SatK), Savon Sanomat (SaS), Suomen Kuvalehti (SK), Turun Päivälehti (TP), Turun Sanomat (TS) ja Uutispäivä Demari (UD). Aineisto on kerätty osana laajempaa toimihenkilöiden itseymmärrystä koskevaa tutkimushanketta (Anttila \& Levä 2016), josta ilmestyy vertaisarvioitu tutkimusmonografia (Levä 2021). Artikkelin aikarajaus perustuu 1990-luvun alun laman syvimmän vaiheen ajalliseen kestoon vuoden 1991 syksystä vuoden 1993 syksyyn, jolloin neuvoteltiin ensimmäisen vuoden tarkistuksia tulopoliittiseen sopimukseen.

Vaikka lama ei suinkaan vielä aikarajauksen lopussa ollut taloudellisella ja sosiaalisella tasolla ohi, puheen hegemonisten kehysten muutos saavutti tuolloin kyllääntymispisteensä. Sosiaalisella tasolla lama jatkui huomattavasti pitempään, minkä 
ovat tuoneet esille esimerkiksi monet köyhyystutkijat (esim. Kuivalainen 2010) tai lamatutkimus (esim. Kiander \& Vartia 1998; Kettunen 2002; Outinen 2015). Laman jatkuminen on osaltaan seurausta juuri tässä tarkasteltavista uusista puhekehyksistä.

Aineistokuvaus tapahtuu temaattisesti. Aineistojen hankintaa ohjasi kysymys siitä, millaisin toimintaa ohjaavin ilmauksin työelämän tilanteesta lamassa puhuttiin. Tutkimuskysymykset olivat:

1) Millaisena lamatilanne lehdissä nähtiin ja mitä ratkaisuja sille esitettiin?

2) Millaisia ehtoja työntekijöille asetettiin uudistuvassa työelämässä?

3) Miten työelämään liitetyt ajatukset vaikuttivat työtä koskevaan psykologiseen sopimukseen ja työelämän subjektiviteetteihin?

\section{Teoria: Jälkistrukturalistinen kieliteoria ja lehdistön käskysanat subjektiviteettien rakentajana}

Tarkastelu tapahtuu Deleuzen ja Guattarin (1972; 1980; 1991) kapitalismiteorian kautta. Heidän näkemyksensä historiallisesta muutoksesta perustuu ajatukselle kapitalismin jatkuvasta muuntumisesta pääomien pyrkiessä sisäisen logiikkansa eli lisäarvon tuottamisen pakosta ylittämään omat rajansa. Kapitalismi nähdään historiaa muodostavana järjestelmänä (Deleuze \& Guattari 1972, 81-82, 143-157; Deleuze 1995, 171). Kapitalismin seurauksena yhteiskuntia hallinneet merkitykset irtoavat aiemmista ikuisilta tuntuneista merkitysyhteyksistä. Merkitysten vapautumisen sijasta vanhojen kurinalaistavien merkitysten tilalle tuotetaan yhteiskunnan haltuunoton prosessissa kuitenkin uusia kapitalismin logiikan mukaisia markkinoitavissa olevia kelluvia merkityksiä. Koska mitään universaalia pysyvää merkitystä ei ole olemassa, perustuvat yhteiskuntien valitsemat toimintamallit aina niissä vallitsevien uskomuksien kamppailussa tuotetuille vallanjakoa koskeville kompromisseille, joissa erilaisina sommitelmina (agencement) toimiva sosiaalinen kenttä otetaan yhteiskunnallisen enemmistön haltuun. (Deleuze \& Guattari 1972, 157-187.)

Demokratiaa ylläpidetään keskustelemalla ja osallistumalla poliittiseen prosessiin. Siksi julkinen puhe ei ole samantekevää. (Aslama ym. 2002, 11-12.) Sosiaalinen toimii koneellisesti, ja sen alkukohtana on moniäänisten ruumiiden yhteen kokoaminen. Yhteisöstä tehdään yhtenäinen erilaisten äänien tuottamilla kertosäkeillä 
ja toistoilla, joina lehdistöpuhetta voi pitää. (Deleuze \& Guattari 1972, 81-84, 106110.) Jälkimodernissa kapitalismissa vallitsee "merkitsijän despotismi", jossa kaikki merkit palautetaan merkeiksi jostain yleisestä ja representoidusta todellisuudesta (Deleuze \& Guattari 1972, 119-120). Siksi lehdistöpuhetta on tutkittava tällaisena moniäänisiä ruumiita yhteen kokoavana yksiäänisyyttä ja ryhmäytymistä luovana sommitelmana.

Deleuzen ja Guattarin kieliteoriassa (1980, 95-97) käskysanat (mot d'ordre) toimivat kielen perusyksikköinä. Puheen pohjimmainen määräytyminen ei perustu kielikuville, metonymioille tai metaforille vaan epäsuoralle puheelle (discours indirect). Kaikkiin ääniin sisältyy täten aina useita ääniä, erilaista kohinaa tai kielillä puhumisia, joiden alkuperä ei palaudu yksilölliseen puheeseen. Kieli on aina toisen puhetta kolmannelle eli kuulopuhetta siitä, mitä joku on kuullut tai mitä joku toinen on sanonut. Kielen toimintaa tulee ymmärtää karttana, ei jäljennöksenä. Kieli välittää aina vain juuri sen verran informaatiota kuin on tarpeen käskysanojen viestin havaitsemiseksi pakottaviksi määräyksiksi. Käskyt liittyvät aina aiempiin käskyihin ja ovat siksi ylimääräytyneitä (redondance) pakottaen kuulijoiden mieliin semioottiset koordinaatit, jotka ilmaisevat vallan kieliopin kaksinaiset perusteet sosiaalisella kentällä ja tuottavat ruumiiden identiteetit.

Osoittavuuden ja määräävyyden lisäksi kielellä on sisäsyntyinen yhteys puheen ja toiminnan välillä eli performatiivista (tekevää) ja illokutionääristä (ehdollistavaa) voimaa. Ehdollistavuus konstituoi julkilausumattomia olettamuksia ja näkyy puheen kollektiivisissa sommitelmissa (kuka tekee mitä, missä ja kenen kanssa). Käskysanoihin sisältyy näin suora tai epäsuora sosiaalinen velvoite toimia. Ylimääräytyneisyyden ensisijaisuus toimii sanojen välittymisen pienimpänä ehtona. Se tapahtuu toistoissa tai resonansseina, joissa kuulijoille tuotetaan läheisyyden tuntua. Puheen merkityksellisyys ja subjektivointi riippuvat tästä, ja siksi lehdistö ja muu tiedonvälitys hyödyntävät ilmiötä. Ne haluavat kertoa meille, miten meidän tulisi ajatella, mitä tulisi säilyttää ja muuttaa sekä mitä odottaa. Jokainen lausuma suorittaa jonkin toimen, ja tämä toimi suoritetaan lausumalla se. (Deleuze \& Guattari 1980, 98-100; vrt. Austin 1962, 100-139.)

Pääomaresurssit ja valta stabilisoivat kieltä, jolloin sanoman puhujan asemalla on erityistä merkitystä. Yksinäinen liikekannallepanon julistaja torilla ohjataan todennäköisesti avohoitoon tai jätetään huomiotta, mutta valtaa hallussaan pitävän johtajan julistaessa yleisen liikekannallepanon se tapahtuu. Vallan merkitsijä tekee 
lausumasta uskottavan. (Deleuze \& Guattari 1980, 14, 107.) Sosiaalisen määräytyneisyyden ja kausaalisten ketjujen lisäksi historialliset tapahtumat sisältävät aina kuitenkin myös jotain muuta: poikkeamia sosiaalisista normeista ja totunnaistavoista. Nämä tuottavat sosiaaliselle kentälle epävakaita tiloja, jotka avaavat mahdollisuuden uudelle. Tuleva ei siis koskaan ole täysin suljettu, vaan myös tapahtumat itsessään osallistuvat sen tuottamiseen. Tämä synnyttää uudenlaisia subjektiviteetteja (suhde työaikaan, ruumiiseen tms.) sosiaalisella kentällä. Nämä "sosiaalisen mutaatiot" eivät synny talouden tai politiikan kausaliteetteina, vaan ne vaativat toteutuakseen kollektiivisten toimijoiden puhetta, jossa tehdään näkyväksi se, mitä yhteiskunnan sosiaaliselle kentälle tuotetaan haluttavaksi. (Deleuze 2006, 233-234.)

Lehdistöpuhe muokkaa julkisena puheena sommitelmissa toimivia kollektiivisia alitajuntoja, kulttuurisia mielikuvia ja hegemonisia puheenkehyksiä tietoiseksi poliittiseksi toiminnaksi ja subjektiviteeteiksi. Tutkimuskohteena on ilmiön rakenteistuminen suomalaiseen työelämään (vrt. esim. Heiskala 2003). Kulttuuri ymmärretään eläväksi järjestelmäksi, jossa vallitsee analogia sen ja jäsenten subjektiviteettien välillä (Lotman 1990, 123-142). Lamatekstejä luetaan toiminnallisina julkilausumina ja pohditaan, millaisia tehtäviä ne historiallisina aikaan ja kontekstiin sidottuina ilmiöinä asettivat laman jälkeisen työelämän toimijoille. Artikkelissa esitetään Peter Sloterdijkin (2013, 8-9) mukaan, ettei julkisella lamapuheella niinkään välitetty informaatiota vaan luotiin eräänlaisia kommunikoivia ryhmäruumiita. Puhetavat merkitsevät ja tuottavat poliittisia seurauksia, jolloin yhteiskuntaa luonnehdittaessa rajataan tai laajennetaan sen poliittista tilaa (Kettunen 2002, 15; ks. myös Julkunen 2001, 12; Suoranta 2009).

Tutkimuksen kohteena olevaa muuntumista, jossa jokin ilmiö muuttuu kriisiksi nimeämisen kautta ilman, että sille hahmotetaan yhtä selkeästi havaittavaa ulkoista syytä, voi yrittää ymmärtää sumeana logiikkana. Kyse on yhteiskunnan monitahoisesta verkostomaisesta (meshwork) prosessien sommitelmasta (agencement), jonka määrittäminen johonkin yhteen yksittäiseen asiaan on mahdotonta ilman yhteiskunnallista valta-analyysia. (Varela 1991; Rodríguez-Giralt 2014; Sarkki ym. 2020.) Artikkeli haarukoi ilmiötä lehdistöstä. Pelkistämällä esiin puheen toiminnallinen puoli voidaan tavoittaa yhteiskunnan toimintapyrkimyksiä suuntaava dynaaminen mallinnus eli vallan kieliopin käskysanat. 


\section{Työn psykologisen sopimuksen historia}

Käsite työn psykologinen sopimus syntyi anglosaksisessa työelämätutkimuksessa. Argyris (1960, 96-97) käytti käsitettä tutkimuksessaan työläisten ja työnjohtajien välisistä suhteista ja pohjasi ideansa Menningerin työhön potilaan ja terapeutin välisestä sanattomasta sopimuksesta. Argyriksen mukaan optimaalisinta tulosta tuotettiin passiivisen johtamisen alaisina tilanteissa, joissa työnjohto kunnioitti työläisten omaan päätäntävaltaan perustuvia epämuodollisia käytänteitä. (CoyleShapiro \& Parzefall 2008, 18; Saari 2014, 29-31.)

Levinsonin tutkijaryhmä (Levinson ym. 1962, 20-21) havaitsi työntekijöiden puhuvan työstään odotuksina, joiden täyttämisestä oli vastuussa työnantaja. Tämä odotussuhde määriteltiin työn psykologiseksi sopimukseksi (Psychological Contract, $P C)$. Se oli vastavuoroisten odotusten suhde, jonka ehdoista kumpikaan osapuoli ei ollut selvillä täsmällisesti mutta joka ohjasi vuorovaikutusta. Schein (1965) painotti omissa tutkimuksissaan suhteen systeemistä laatua ja molempien osapuolten odotusten täyttämistä. (Ks. esim. Anderson \& Schalk 1998, 638-639; Coyle-Shapiro \& Parzefall 2008, 18-22.)

Rousseau (1989) laajensi työn psykologisen sopimuksen määritelmää työntekijöiden mielissä vaikuttaviksi julkilausutuiksi tai julkilausumattomiksi lupauksiksi. Taloudellisten taantumien, työn uudelleenjärjestelyiden ja yritysten henkilöstövähennyksien on havaittu vaikuttavan tulevaisuuden odotuksiin: erityisesti omasta vapaa-ajasta tingitään. Myös ulkoisia vaatimuksia siedetään enemmän. (Ks. esim. Smithson \& Lewis 2000, 680-702; De Hauw \& De Vos 2010.)

\section{Laman tapahtumahistoriallinen tausta}

Suomalaiset työpaikat joutuivat 1990-luvulla "muutosmyrskyyn" (Heikkilä 1998). Kotimaisen kysynnän romahdus synnytti laman. Neuvostoliiton samanaikainen romahdus avasi tien globalisaatiolle, joka oli Suomessa alkanut jo viimeistään 1980-luvulla, kun rahoitusmarkkinat oli avattu. Työnantajien keskuudessa puhe joustavuudesta alkoi samoihin aikoihin. Ajatus liian suuresta julkisesta sektorista oli syntynyt jo 1970-luvun lopulla, jolloin hyvinvointivaltiota ryhdyttiin tulkitsemaan puhtaasti hallinnon käsittein. Hallinnon uudistaminen aloitettiin laman myötä 
valtiovarainministeriön tuella. Hegemioniaprojekti uudenlaisen yhteiskunnan rakentamiseksi alkoi siis jo ennen lamaa. (Kiander 2002; Eräsaari 2002; 2015; Yliaska 2015.)

Lamassa kansainvälisen kilpailun merkitys lisääntyi ja kasvu pysähtyi syventäen lamaa. Yhtiöt ryhtyivät karsimaan kustannuksia ja alensivat hintojaan pyrkien dramaattisiin tuottavuuden parannuksiin. Tämä vaikutti kokemukseen työstä ja sen merkityksestä, sillä samaan aikaan työttömien määrä kasvoi ennätyslukemiin. Lisäksi määräaikaiset työsuhteet yleistyivät, ja työpaikkaa vaihdettiin aiempaa enemmän. (Ilmakunnas \& Maliranta 2000, 239; Siltala 2004; Ojala 2017.)

Ansiosidonnaista työttömyysturvaa heikennettiin ja peruspäiväraha jaettiin kahtia luomalla sen rinnalle uusi työmarkkinatuki (Outinen 2015, 241). Tämä oli yritys kontrolloida kasvaneita työttömyysmenoja. Peruspäivärahan ehdoksi määrättiin työmarkkinatukea luotaessa vähintään kuuden kuukauden työhistoria ja osallistuminen aktivoimistoimenpiteisiin tai koulutukseen. Ansiosidonnainen työttömyysturva kuitenkin säilytti asemansa, koska ammattijärjestöt puolustivat sitä aktiivisesti. (Timonen 2002, 257-258, 264.)

Suomessa on teollisena aikana vallinnut alhainen työttömyys. Tavoitteena on suurimman osan aikaa ollut täystyöllisyys. Ruotsalainen yhteiskuntatutkija Göran Therborn ajatteli vielä vuonna 1986, että Suomella näytti "olevan todellinen mahdollisuus saavuttaa täystyöllisyys tulevina vuosina". Poikkeukseksi muodostuivat 1930-luvun lama, 1970-luvun alun öljykriisin jälkeinen lyhytaikainen lama palkkatyön yhteiskunnan toteuduttua Suomessa sekä 1990-luvun lama, joiden kaikkien aikana työttömyysluvut kasvoivat merkittävästi. (Kalela 1989, 17-25.)

1990-luvun laman jälkeen työttömyysaste ei palannut enää aiemmalle tasolle. Ilmiötä on kutsuttu työttömyyden hystereesiksi (Räisänen 2020, 7-8). Myös pitkäaikaistyöttömien korkea määrä jäi laman myötä pysyväksi ilmiöksi (Halmetoja 2016, 127). Ennen vuoden 2008 finanssikriisiä työttömiä oli EVA:n mukaan vielä reilut 6 prosenttia. Finanssikriisin myötä työttömyysaste kasvoi vuoteen 2015 tultaessa lähelle 10 prosenttia. Vaikka se on tämän jälkeen ajoittain pienentynyt, oli työttömiä silti tammikuussa 2020 ennen koronaepidemiaa edelleen 7,2 prosenttia työvoimasta. (EVA Työttömyysaste; Työvoimatutkimus 2020.)

Täystyöllisyyden tavoittelu ei ole laman jälkeen ollut keskeisin politiikkakohde. Pyrkimyksenä on ollut nostaa työllisten osuutta väestöstä ja saada työssä olevat pysymään työelämässä pidempään. (Ks. esim. Outinen 2015, 245, 310-315.) Työttö- 
myydestä uutisointi ylittää uutiskynnyksen aiempaa harvemmin ja keskittyy työllisten määrän kasvattamiseen. Työttömyyden puuttuminen uutisoinnista kertoo hiljaisesta hyväksynnästä ja käsitteellisestä muutoksesta, jossa työelämää koskevien vaikutusmahdollisuuksien ajatellaan pienentyneen aiempaan verrattuna. (EVA Työttömyysaste; Outinen 2015; Työvoimatutkimus 2020.)

Logistisen kiristymisen seurauksena akateemiset työntekijät tekivät korvauksetonta ylityötä aiempaa enemmän, ja koska työpaikat eivät olleet yhtä vakaita kuin aiemmin, he tekivät muita toimihenkilöitä pidempää työviikkoa. Ylin johto teki 51 tunnin työviikkoa vuonna 2005. Työssä jaksamisvaikeudet lisääntyivät. Viikkotyöaika akavalaisilla oli vuonna 2014 edelleen keskimäärin 41 tuntia. Näennäisyrittäjyys kasvoi toimihenkilöammateissa. (Ks. Akava uutiset - nytt 3/92, 32-33; Akavan työmarkkinatutkimus 1993, 42; 1996, 51; 1997, 59; 1998, 56; 2001, 67; 2002, 73, 76-81; 2003, 70-75; 2004, 73-74, 80; 2005, 27; Akavaaka 2014, 28.) Itsensätyöllistäjien määrä on nykyisin jo yli 160000 henkilöä (Lamponen 2019, 61-96; ks. myös Halmetoja 2016, 127).

\section{Aineiston analyysi: Lamassa tuotettu muutospuhe lehdistössä}

Lama oli lehtien palstoilla elämistä sota-ajan pysähtyneisyydessä. Lama sanana viittaa jo itsessään lamautumiseen ja pysähtymiseen. Sotatila ja kriisin aiheuttamat militantit tuntemukset mahdollistivat muutoksen, sillä "asemasota" kaipasi ratkaisua (SatK 25.3.1992). Lehdissä käytiin markan puolustussotaa (SK 10.4.1992) ja toivottiin "talvisodan hengen" uudelleen syntymistä (SK 14.8.1992). Työnantajat olivat järjestyneet "falangiksi" (IS 19.10.1993).

Muutosviesti oli sisäistynyt hyvin, sillä Keskustapuolueen äänenkannattajassa Pohjolan Sanomissa toimihenkilöiden ammatillisen keskusjärjestön STTK:n järjestösihteeri kertoi, että on "pakko karsia, säästää ja sopeuttaa" (PoS 29.2.1992). Riippumattomassa mutta aiemmin pitkään keskustapuolueen äänenkannattajana toimineessa Keskisuomalaisessa vaadittiin, että velkarahalla pitää saada "pyörät pyörimään". Tällaisella nitrolla talouden "sydän saataisiin pelaamaan". (KSML 11.3.1992.) 
Velanoton hyväksyminen kertoi epävarmuudesta, joka merkityksellistettiin suomalaisille tutuilla sotakuvastoilla (vrt. Rentola 2005). Oltiin muutostilanteessa, jossa aiempi kansallinen talous oli lopullisesti pakotettu integroitumaan ylikansalliseen talouteen järjestelmän autonomisuutta ylläpitäneen Neuvostoliiton kaupan romahdettua. Vanha fordistinen kasvu- ja kasautumismalli tuli tiensä päähän. Noudatettu keynesiläinen makrotalouspolitiikka korvattiin uusklassisen taloustieteen tasapainomalleilla. Tutkimus on kutsunut tätä siirtymäksi postfordistiseen malliin, jota toteutettiin uusliberalistisella politiikalla. (Koistinen 2014, 23-30.) Uusklassisen talousteorian näkemyksiä ei tarvinnut perustella, vaan todisteluvastuu oli epäonnistuneiksi katsotuilla teorioilla. Sota on aina myös poikkeustila, jonka aikana yksilöiden oikeuksia voidaan vähentää kokonaisuuden edun vuoksi. Sotapuheelle on Suomessa ollut historiallisten ja geopoliittisten syiden vuoksi pitkään altis maaperä. Sota oli juuri se lamapuheeseen liittynyt ylimääräytyneisyys, joka toimi sanoman läpimenon välttämättömänä ja pienimpänä ehtona.

Lehdistön puheet toimivat muutoksen käskysanoina. Toistoilla ja samastumisilla tuotettiin puheelle uusi hegemoninen kehys. Ajelehtiminen markkinavoimien armoilla hyväksyttiin. Hyvinvointivaltiolliset rakenteet nähtiin moraalittomina, mistä seurasi tarve siirtää vastuu yksilöille. Vaikka sitoutumaton Länsi-Savo kertoi "säästämisen" menneen "järjettömäksi", epäiltiin ainoastaan, että "katkeroituneet" saattaisivat "hermostua" (LS 13.10.1993). Kokoomuksen aiempi äänenkannattaja Satakunnan Kansa vaati ryhtymistä "säästökuurille langanlaihan laihduttamiseksi" (SatK 13.10.1993). Työnantajapuolta tukenut Iltalehti totesi, että "aika" oli jo ehtinyt kulkea ohi "vanhentuneiden ja joustamattomien työmarkkinamekanismien". "Pelastus" tapahtuisi "kriisien kautta dramaattisesti". (IL 6.10.1993.) Kriisi on metafora, joka antiikin kreikan filosofeilla viittasi taudin kannalta ratkaisevaan kahtiajakautumiseen ja käännekohtaan. Valtaa tilanteen arvioimisessa käytti krino eli tuomari, joka lamassa oli lehdistö. (Stiegler 2015, 28.)

Kriisi liittyy sotaan, sillä sodissa kuolee aina sivullisia uhreja. Zygmunt Bauman tulkitsee, että viimeaikaisella työllisyyspolitiikalla köyhistä ja työttömistä on tehty tällaisia "sivullisia uhreja" (collateral damage), koska työttömyyden estämisestä seuraavien menojen ei ajatella olevan tarpeeksi tärkeitä oikeuttamaan niihin käytettäviä kustannuksia. (Bauman 2011, 8; ks. myös Kuivalainen 2010). Deborah Cameronin (1995, 72-75) mukaan käsitteen abstraktius ja tunteettomuus pyrkii häivyttämään mahdollisuuden nähdä käsitteen käytöllä perusteltavien tekojen 
vastenmielisyys. Vallalle nousseen totuuden työttömistä sai lehdissä pelkistää kasvatustyöntekijä Arvo Järvelä. Hänestä "ikivanha maatiaisjärki" sanoi, ettei "suosta nousta velkaa ottamalla, eikä pinnareita suosimalla, vaan raakaa työtä tekemällä". (TS 6.10.1993.) Myöskään nuoret ja pitkäaikaistyöttömät eivät kyenneet puolustamaan etujaan lamassa, toisin kuin ammattijärjestöt, jotka kykenivät suojelemaan etujaan kohtuullisesti myös laman aikana (Timonen 2002, 255-266).

Aikoina, jotka julistetaan kriiseiksi, vaaditaan kollektiivista uhrautumista (Graeber 2018, 194). Lamassa vaadittiin "yhteiseen hiileen puhaltamista" (ESS 28.10.1993), ja uhrautuminen koski myös keski-ikäisiä (IL 17.11.1993). Työtätekevät ruumiit jaoteltiin lehdistössä menestyjiin ja sivullisiin uhreihin "Koroman kenttäoikeuden" istuessa (IL 19.10.1993). Ajatus uhrien sivullisuudesta sai heidän kohtalonsa tuntumaan yksilöityneille menestyjille siedettävämmältä, koska sivullisuus viittaa välttämättömyyteen, joka kohtaa jotain toista ja oikeuttaa oman selviytymisen. Työttömyys hyväksyttiin tilastojen kasvottomuuden vuoksi, mutta sen poistaminen jätettiin työttömien omaehtoisen itseorganisoitumisen varaan. (Hertzen 2010; Levä 2019.)

Työttömyys nostettiin ajan moraaliseksi ongelmaksi. Sitä tulkittiin negatiiviseen sävyyn ja työttömiä samalla tavoin syyllistäen kuin jo 1930-luvun lamassa (ks. Kalela 1989, 83-89), vaikka yhteiskunnan rakenne oli täysin muuttunut. Palkkatyön yhteiskunnan syntymisen jälkeen 1970-luvulla työtön leimattiin "epänormaaliksi yksilöksi", sillä hänen ajateltiin elävän muiden kustannuksella (Vähätalo 1983, 165; Kalela 1989, 209). Siksi työttömyys synnytti häpeää ihmisissä myös laman aikana. Jopa Uutispäivä Demarissa spekuloitiin, oliko työttömien "laiskuudesta tullut uusi hyve?" (UD 24.11.1993). Valtiovarainministeri Viinasen suulla syytettiin sairausfantasiaa vahvistaen "työttömyysturvan" olevan "yhteiskunnan syöpä" (TS 1.9.1993; HS 3.9.1993; HS 5.9.1993; UD 10.11.1993). Syy lamasta siirrettiin työttömiin syntipukkeihin, joita pidettiin kurittomina ja ahneina. Jouluna 1992 Suomen Pankin osastopäällikkö Johnny Åkerholm haki "lamasyyllisiä". Hänen mukaansa "jälkiistunnon välttämiseksi" työmarkkinoilla tuli olla lisää joustavuutta ja julkisia menoja oli leikattava. (AL 20.12.1992.) Ihmisten haluttiin olevan "tietoisempia" lamasta (SaS 23.4.1992).

Mediajulkisuuden vaikutus poliittisessa päätöksenteossa kasvoi 1990-luvulla. Lamakirjoittelu näki lama-ajan katkoksena aiempaan ja tuotti uusia puhetapoja. Esa Reunanen ja Jari Väliverronen $(2020,85)$ huomauttavat ay-liikkeen ja työnantajien 
osuuden työelämäpuheesta kasvaneen lehdistössä huomattavasti. Kansantalouskehys ryhtyi hallitsemaan toimituksien mielipidekirjoittelua. Toki ay-liikkeen vaatimuksiakin esiteltiin. (Emt. 8, 103, 106, 115, 121, 143, 177-178; ks. myös Aslama ym. 2002, 11-13).

Tilanteeseen tarjottiin ratkaisuja hyvissä ajoin, sillä jo marraskuussa 1989 ennen lamaa Suomen Pankin pääjohtaja Rolf Kullberg totesi julkisuudessa: "Kysyntä Suomessa on pakotettava alas, tarpeen vaatiessa se on tehtävä luomalla Suomeen keinotekoinen taantuma." (LS 4.11.1989). Ratkaisuna neuvottelujärjestelmän ongelmiin esitettiin yrityskohtaista sopimista (SaS 23.4.1992), ja laman torjunnassa nähtiin tarvittavan myös "psykologiaa" (TP 1.10.1993). Lamaa edeltänyt huikentelevainen tuhlaus ei muuttuneiden käsitysten mukaan enää käynyt vaan oli nyt syvästi epämoraalista toimintaa. Samaan aikaan työelämän rakenteiden kerrottiin olevan vanhentuneita ja joustamattomia (IL 6.10.1993; AL 22.10.1993), minkä vuoksi oli sorruttu lamasyöverien kaaokseen (P 29.10.1993; ES 4.11.1993). Jos talouskeppiä ei uskottaisi, katsottaisiin teuraskirjasta seuraukset (IL 4.11.1993).

Lehdistö rakensi uudeksi työelämän toimintaympäristöksi jatkuvan kilpailun yhteisön, jossa yksilöiden tehtävä oli toteuttaa darwinistista survival of the fittest -ideologiaa markkinavoimien ehdoin (Glynn 2020, 17-21). Keskustalaisessa Ilkkalehdessä pohdittiin, miten "välttämättömyyteen" sopeuduttaisiin. Vastaus oli, että "ihminen" tulisi olemaan "ihmiselle susi". Syrjäytyviä olisi kuitenkin liikaa "susilaumaksi", joten edessä oli "äärimmäisen tuskallinen prosessi". Lehti esitti, että työtä tuli tehdä halvemmalla, koska markkinatalous oli "luonnollista ja oikein", ja otaksui "kaupan hirmuisen pudotuspelin" jatkuvan. Jäljelle jäisi ainoastaan "terveitä", koska yritykset tarvitsivat "rakennemuutoksen". Markkinaehtoisena tämä muutos tulisi tapahtumaan "vahvemman oikeutena". (I 3.10.1993.) Kaikki ratkaisut tilanteeseen tuli lehtien mukaan tehdä "markkinoiden ehdoilla" (SatK 1.10.1993) eikä markkinavoimia saanut "säikyttää haamuilla" (HS 1.10.1993). Myös Uutispäivä Demarissa todettiin, että oli "opittava toimimaan muutoksen ja epävarmuuden tilassa" (UD 24.11.1993).

Hyvinvointivaltiosta tehtiin moraalisesti arveluttava ja epämääräisesti mitattava, joten sitä piti muokata paremmaksi ja helpommin mitattavaksi. Tehostaminen ei kuitenkaan ollut yhtään vähemmän arvolatautunutta tai rationaalisempaa kuin hyvinvointivaltion tavoitekaan vaan perustui valtavirtataloustieteen teorioiden uskomuksille täydellisestä kilpailusta ja markkinoiden hakeutumisesta tasapainoon, 
joille ei ole löytynyt reaalimaailmasta riidatonta näyttöä (ks. esim. Ahokas ym. 2018, 25-48). Lehdistössä uudella puheella tuotettiin edellytyksiä aiemmin esille nostettujen tavoitteiden läpimurrolle toistelemalla uusia käsityksiä johdonmukaisesti (Eräsaari 2015; Yliaska 2015).

Suomessa alkoi 1990-luvulla työmarkkinoiden polarisaatio. Sekä korkeapalkkaiset että matalapalkkaiset työt ovat lisääntyneet, ja keskipalkkaisten työpaikkojen osuus on pienentynyt. (Matalapalkkatyö Suomessa 2013; Paavola ym. 2019.) "Paskatöiden" yleistymistä tutkinut David Graeber selittää uuden järjestelmän pysyvyyttä juuri psykologisen sopimuksen muuttumisella. Koulutustaso on noussut. Koulutetut ja yleensä paremmin palkatut työntekijät pelkäävät eniten oman asemansa menetystä eivätkä kritisoi itse järjestelmää. (Graeber 2018, 168.)

Kansallisen talouden sijaan astuneen globaalitalouden pienin toimija oli yritys. Sitä sielutettiin lehtien kommenteissa eläväksi. "Markkinoinnista on tullut yrityksen keskus tai 'sielu'. Meille opetetaan, että yrityksillä on sielu..." (Deleuze 1995, 181). Lehtien palstoilla Suomessa oltiin tilanteessa, jossa ulkoinen uhka ja ponnistelun pakko syrjäyttäisi "itsetuhomietteet" (ES 18.10.1993). Toiminta poistaisi ahdistuksen. Mallia tästä oikeasta toimintamallista antoi yrittäjä Kari Räihä, jolle oma yritys oli "kuin pieni lapsi", jota piti "hoivata ja vaalia" (R 21.10.1993). Häpeää ei lehdistöpuheen mukaan saanut ilmaista. Se olisi merkinnyt vastavuoroisen hyväksynnän puuttumista eli mielikuvilla rakennetun kilpailukyky-yhteisön ryhmäjäsenyyden menettämistä. (Ks. Anderson 1983; Siltala 2004; Stiegler 2010, 77-114, 192-206.)

\section{Tulkinta: Yksilöidyt subjektiviteetit laman mallityöntekijöinä}

Juha Siltalan ja Raija Julkusen mukaan aiemmin kollektiiviseksi vastarinnaksi ja vastakkainasetteluksi kanavoidut työelämän jännitteet ja turhaumat kanavoidaan nykyään yksilöiden ongelmiksi (Siltala 2004, 43-45, 102-135, 158-190; Julkunen 2008, 11). Ihannetyöläisen subjektiviteetit muuttuivat lamassa: oli tehtävä itsensä tarpeelliseksi. Valvonta subjektivoitui itseä sekä työtovereita koskevaksi kurin sisäistyessä kontrolliksi. (Flecker \& Hofbauer 1998.) Tutkimus puhuu "petetystä keskiluokasta" (Sennett 2002, 10-29, 45-64, 104-126; Ehrenreich 2006, 11-13; Siltala 2017). 
Akseli Virtasen mukaan talous on kriisiytynyt biopolitisoituessaan. Ihmisen kommunikatiiviset kyvyt on integroitu tuotannon tekijöiksi. Kapitalismi on siirtynyt operoimaan suoraan ihmisten elämissä ilman välityksiä, kuten tehdas ja työaika. Arvoa tuottavat sanat. Kaikki toiminta on ymmärrettävissä työnteoksi ja tuotteistettavissa, mutta näin ei aina tapahdu, koska ei nähdä markkinoita. Ajattelun suora haltuunotto tarkoittaa rajoittuneen talouden päättymistä. Työlle se merkitsee pahimmillaan sen teettämistä korvauksettomana harjoitteluna, lupauksella myöhemmästä hyödystä (vrt. Julkunen 2001, 179-181). Tällaisena talousmuotona uusi talous ei enää tarvitse perusteita, joten Virtanen nimeää sen mielivallaksi. (Virtanen 2006, 13-18.)

Monet työmarkkinoiden ilmiöt tuotteistettiin lamassa. Työläisten tuli olla joustavia ja sitoutua yritysten tavoitteisiin. Palkkatyön normiksi nostettiin käsite yrittäjyys. Omaa elämää piti tarkastella portfolioprojektina, jossa itseä kehitetään yhä paremmaksi tuotteeksi. (Kettunen 2002, 24-27.) Tämä vaikutti työtä tekevien ruumiiden subjektiviteettiin. Jussi Turtiainen, Erkko Anttila ja Ari Väänänen ovat havainneet, että muutokset ulkoisissa olosuhteissa vaikuttivat monin tavoin sosiaalityön ammattilaisten sisäiseen tunnesäätelyyn laman jälkeen (Turtiainen ym. 2020). Suomalainen työn kulttuuri painotti jo ennen lamaa pärjäämisen arvoa (Kortteinen \& Tuomikoski 1998, 24-30; Siltala 1994; 2004) edesauttaen vaaditun muutoksen omaksumista.

Käsitys ihanteellisesta työntekijästä muuttui, ja työntekijältä vaadittiin yhä lukuisampia kykyjä ja ominaisuuksia. Työ emotionalisoitiin, ja piti heittäytyä työn imuun. Myös johtajuus muuttui: käskemisestä siirryttiin suostutteluun, ja oli omaksuttava uusia psykoemotionaalisia kykyjä. Organisaatioiden keventäminen ja joustavoittaminen siirsi työnteon tiimeille ja vastuun suorittavalle tasolle. Toimihenkilöiden tultua enemmistöksi työvoimasta työntekijöiden keskimääräinen koulutustaso nousi. Tilanne johti työpaikoilla tunnetaitojen hallinnan kontrolloimiseen ja näiden epävirallisten taitojen byrokratisoitumiseen. (Varje 2018, 53-58; ks. myös Vähämäki 2003, 78-97; Siltala 2004; Saari 2014; Mannevuo 2015.) Kaiken piti tehostua ja kasvaa jatkuvan kilpailun työelämässä. Oli muututtava, jotta kykeni olemaan kilpailukyky-yhteisön jäsen.

Randy Hodson (2001, 134-139, 195-199, 231-236, 269) muistuttaa työnteossa olevan taloudellisten kannusteiden lisäksi kyse myös yksilöllisestä arvokkuudesta. Työ on itsetoteutuksen muoto, jopa eräänlainen turvapaikka ja intohimo: siksi 
ihmiset usein joustavat ja tekevät ylimääräistä säilyttääkseen omanarvon tunteen. Ilmiötä kutsutaan tutkimuksessa resilienssiksi. (Ks. esim. Luthar ym. 2000.) Monilla läntisen Euroopan työpaikoilla 1990-luvulla solmittu uudenlainen työn psykologinen sopimus tarkoitti pidempien työtuntien kulttuuria (Cooper 2002, 355). Uudistetussa työelämässä oli kyse pääsystä johonkin (Rifkin 2000). Yksilöity "työahdistus" syntyi: pelätään, ettei työttömyyttä kohdattaessa enää ikinä päästä uudelleen työelämään takaisin (Bardini 2011, 163-164). Yksilöitymisestä kertoo myös 1990-luvulla alkanut puhe valmentajavaltiosta, jossa yksilöitä sparrattiin sopeutumaan paremmin kokonaisuuden ehtoihin (Heiskala \& Kantola 2010, 138; vrt. myös Kantola 2002; Mustakallio 2003; Sitra 2004; Lazzarato 2014, 77-78; Saari 2014, 19-20).

Lamassa tuotettu mallisubjektiviteetti vaikuttaa Tähtilaiva Enterprisen miehistöltä yhteen muottiin puristettuna: "Jokaisella miehistön jäsenellä on tarpeellinen tehtävä: Kirk on peloton tutkija, Scotty lojaali palvelija, Spock kaikkitietävä sekä Uhura silmät ja korvat. Mutta työntekijän oletetaan olevan kaikki nämä yhdessä - kansainvälinen, lojaali, oppivainen ja tarkkaileva, mikä vaikeuttaa tilannetta. Odotusten paino ei ole ainoastaan uskomattoman raskasta kantaa vaan myös ristiriitaista." (Herriot 1992, 44. Suom. IL.) On oltava työelämälaiva Enterprisen moniosaaja tai työtön sivullinen uhri. Molemmat esitetään omina "valintoina". (Lazzarato 2012, 9.) Satu Ojala huomauttaa, että koko työvoimapolitiikka muuttui lamassa. Työttömien aktivointi kohdistui sen jälkeen pelkästään yksilöihin (Ojala 2016, 106). Työsuhteensa säilyttäneet joutuivat julkisessa puheessa tuotettujen kaksoissidoksien vuoksi valintatilanteeseen, jossa oli vain huonoja (jatkuva logistinen kiristyminen) tai vielä huonompia vaihtoehtoja eli työttömyys (Bardini 2011, 156, 160-161, 170, 188; kaksoissidoksesta ks. Bateson 1972, 206-210).

Muutos jäi pysyväksi, koska yläkäsitteenä toimi tehostaminen. Työelämän muuttuneilla odotuksilla on ylisukupolvisia seurauksia. Jaakko Kianderin (2002, 61) mukaan lamapuhe oikeutti tehtyjä valintoja. Siksi uudistukset jäivät pysyviksi. Lamanjälkeiset työmarkkinoille tulijat kasvoivat uuteen työn psykologista sopimusta koskevaan maailmanhahmotukseen. Ehdot omaksuttiin perustaviksi kuviksi ihannetyöntekijästä: joko kiihdytetään vauhtia "multitaskaajina" tai pyritään nopeasti ulos oravanpyörästä (ks. esim. De Hauw \& De Vos 2010; Ronkainen \& Punamäki 2013; Jakonen 2015, 191; Maczulskij 2016; 2018; Silvennoinen ym. 2018; Suhonen 2020, 87-88). Laman yhdistyessä globalisaatioon suurena käänteenä ja pysyvän tuntuisena 
poikkeustilana se vaikuttaa jatkossakin prekarisoituvilla työmarkkinoilla (ks. myös Julkunen 2001; Saari 2014, 5, 19-20; Jakonen 2015).

\section{Johtopäätökset: Uusi työn psykologinen sopimus ja työsubjektiviteettien tuotanto lamassa}

Lamapuheen muutos ei ilmaantunut tyhjästä vaan pohjasi 1980-luvulla alkaneeseen uusliberalistiseen muutospuheeseen. Poikkeustila luonnollistettiin: tekemällä lamasta sodankäyntiä ja puhumalla syistä sekä seurauksista yksilöiden ongelmina muokattiin tapoja, joilla työelämä piti ymmärtää kilpailukyky-yhteisössä. Subjektiviteetteja roolitettiin tietynlaiseksi vaatien uhrautumista kokonaisuuden hyväksi. Työttömien esitettiin olevan itse syypäitä omaan tilanteeseensa. Taustalla olevia rakenteellisia syitä ei haluttu myöntää, koska se olisi kyseenalaistanut koko työelämän mielekkyyden. Lamassa yhteiskunta ja työelämä asetettiin jatkuvaan muutoksen tilaan. Uusia valtakehyksiä ryhdyttiin ylläpitämään laman jälkeen tiedostamattomana kansallisena selviytymisstrategiana. Tästä kertoo aiemmin esitettyjen leikkauksien jatkuminen hallitusten vaihtuessa.

Toimiessaan yhteiskuntakokonaisuuden representaationa mielikuva sotatilasta perusteli leikkauksia, joilla yhteiskunta jakautui kahtia: työpaikkansa säilyttäneisiin tilanteestaan tiedostamattomasti syyllisyyttä tunteviin selviytyjiin ja työttömiin sivullisiin uhreihin. Molemmat ryhmät pysyivät hiljaa, selviytyjät asemansa tuottaman helpotuksen aiheuttaman syyllisyyden vuoksi ja uhrit moraalisen syyllistämisen tuottaman häpeän sisäistymisen vuoksi. Survival of the fittest -yhteiskunnassa työttömyys oli heikkouden merkki, ja heikkona kuuluikin syrjäytyä työmarkkinoilta.

Lama oli poikkeama toimintaa ohjaavista sosiaalisista tavoista: epävakaa kaoottinen tilanne, joka avasi tilaa uusille toimintatavoille. Lehdistö ylläpiti epävakautta tuottaakseen uusliberalismin tarvitsemia uusia yksilöllisiä subjektiviteetteja suomalaisille työmarkkinoille. Vanhan kurinpidon yhteiskunnan kollektiivinen moraali haaksirikkoutui kasinotaloudessa. Uusi yhteiskunta oli kontrolloitujen yksilöiden yhteisö. Työttömyyden institutionalisointia pysyvästi aiempaa korkeammalle tasolle voi pitää kontrolloituna hylkäämisenä tarvittaessa töihin kutsuttavaksi työvoimareserviksi. 
Käskysanojen sisäistämiselle oli kolme syytä: a) elettiin talouskriisin sotaisassa poikkeustilassa, jota lehdet ylläpitivät kirjoituksissaan; b) joustavuutta ja yksityistämistä korostava hallintopuhe oli uutta, ja vanhat keinot oli saatu näyttämään toimimattomilta; c) tilanteesta tunnettiin vanhan luterilaisen työetiikan mukaisesti henkilökohtaista syyllisyyttä, jota uuden työn yksilöimien portfoliotyöntekijöiden keskuuteen konstruoitu kilpailutilanne voimisti. Vaikka lamasota päättyi 2000-luvun alkaessa, ei sitä julistettu missään vaiheessa päättyneeksi. Omaksutuista käytännöistä tuli vallitsevia. Uudet kehykset ovat säilyneet nykypäivään asti, koska lamaa ei ole käsitelty ajatuksellisesti loppuun suomalaisessa yhteiskunnassa.

\section{Epilogi: Työelämän psykologisen sopimuksen tulevaisuus}

Koronanjälkeinen Suomi integroitunee yhä vahvemmin osaksi verkostoituvia globaaleja markkinoita (vrt. Castells 2010, 116-162). Pahimmat viheliäiset ongelmat ovat selvät: yksilöityminen jatkuu, työntekijöiden enemmistöstä saattaa tulla alustatalouden tai loputtomien alihankintaketjujen näennäisyrittäjiä prekaariin työelämään, jossa ei ole enää työehtojen yleissitovuutta tai minkäänlaista kollektiivista neuvottelua. Tällöin myös pysyvästi korkea työttömyysaste hyväksytään yksilöitymisen ja robotisaation sivutuotteena. Yhdeksi työelämän psykologisen sopimuksen keskeiseksi tulevaisuuden kehittämiskohteeksi tulisi tällaisten odotushorisonttien vallitessa ottaa kilpailu vs. yhteisöllisyys -asetelmaan liittyvän kilpajuoksun ehkäiseminen (Häyry 2020), mistä seuraisi työajan jakamista ja työelämän solidaarisuutta sekä tarve määritellä työttömyys uudelleen esimerkiksi perustulon kaltaisen täydentävän tulon kautta.

Työelämän psykologiseen sopimukseen liittyy nykyisin paljon pohdintaa siitä, miten yksilöiden tulisi muuttua sopeutuakseen. Sopeutuminen auttaa tietenkin yksilöitä jaksamaan. Silti yksilöitymisen ja pirstoutumisen seurauksena uskalletaan kuitenkin harvemmin kysyä, miksi työelämä on nykyisin sellaista kuin on. Jos työelämää tarkasteltaisiin globaalina neuvotteluympäristönä, jossa yritettäisiin lähtökohtaisesti ottaa kaikkien edut huomioon, olisi mahdollista kysyä, miten asioita pitäisi muuttaa uuden työn yksilöimien työntekijöiden toteutumattomia mahdollisuuksia eettisesti paremmin huomioonottavaksi kokonaisuuden näkökulmasta käynnissä olevassa työn muutoksessa. (Ks. hyvistä avauksista esim. Koistinen 2014; 
Salovaara 2020.) Kyse on yleisemmällä tasolla koko suomalaisen demokratian toimivuudesta ja siitä, millaiset työelämän yhteisöllisyyden ehdot tulevaisuudessa saavat vallita. Tämä on liian tärkeä asia jätettäväksi yksistään kansallisvaltioiden rajoja pakenevien globaalien työntarjoajien päätettäväksi.

\section{Kiitokset}

Kiitän anonyymeja lausunnonantajia, lehden toimittajia sekä Mika Helanderia, Juha Haavistoa, Ari-Santeri Taljaa ja Hannele Kuusistoa artikkelia kehittäneistä kommenteista. Vastaan kaikista tekstiin jääneistä virheistä ja tutkimuksellisista mielipiteistä yksin.

\section{Kirjoittaja}

\section{Ilkka Levä}

FT, dos., Helsingin yliopisto

sähköposti: ilkka.leva@helsinki.fi

\section{Tutkimusaineisto}

\section{Arkistolähteet}

Akava uutiset - nytt 3/92. Jäsentutkimus 1991. Akavan arkisto, Akava.

Akavaaka tilastokooste 2014. Akavan arkisto, Akava.

Akavan työmarkkinatutkimus 1993, 1996, 1997, 1998, 2001-2005. Akavan arkisto, Akava.

EVA Työttömyysaste 1989-2015. https://www.eva.fi/tyotjatekijat/ tyottomyysaste-1989-2015/> (luettu 10.3.2020)

Työvoimatutkimus 2020. Tammikuu. http://www.stat.fi/til/tyti/2020/01/

tyti_2020_01_2020-02-25_tie_001_fi.html (luettu 10.3.2020) 


\section{Lehdistöaineisto}

Aamulehti 1993 (AL)

Etelä-Saimaa 1993 (ES)

Etelä-Suomen Sanomat 1993 (ESS)

Helsingin Sanomat 1991, 1993 (HS)

Ilkka 1993 (I)

Iltalehti 1993 (IL)

Keskisuomalainen 1992 (KSML)

Länsi-Savo 1989, 1993 (LS)

Pohjalainen 1993 (P)

Pohjolan Sanomat 1993 (PoS)

Raahelainen 1993 (R)

Satakunnan Kansa 1992-1993 (SatK)

Savon Sanomat 1992 (SaS)

Suomen Kuvalehti 1992 (SK)

Turun Päivälehti 1993 (TP)

Turun Sanomat 1993 (TS)

Uutispäivä Demari 1993 (UD)

\section{Kirjallisuus}

Ahokas, J., Alaja, A. \& Eskelinen, T. (2018) Talousteoriat ja työllisyyspolitiikka. Teoksessa J. Kajanoja (toim.) Työllisyyskysymys. Helsinki: Into Kustannus, 25-48.

Anderson, B. (1983) Imagined communities: Reflections on the origin and spread of nationalism. Lontoo: Verso.

Anderson, N. \& Schalk, R. (1998) The psychological contract in retrospect and prospect. Journal of Organizational Behavior 19 (S1), 637-647.

Anttila, A.-H. \& Levä, I. (2016) Tasa-arvotyön toimintatavat ja rakenteet toimihenkilöliikkeessä. Helsinki: TJS Opintokeskus.

Argyris, C. (1960) Understanding organizational behavior. Homewood: Dorsey Press. 
Aslama, M., Kantola, A., Kivikuru, U., Parikka, T., Salovaara-Moring, I. \& Valtonen, S. (2002) Suomen 1990-luvun talouskriisi: demokratian ja julkisen keskustelun koetinkivi. Teoksessa U. Kivikuru (toim.) Laman julkisivut: Media, kansa ja eliitit 1990-luvun talouskriisissä. Helsinki: Palmenia-kustannus, 9-22.

Austin, J. L. (1962) How to do things with words. Oxford: Oxford University Press.

Bardini, T. (2011) Junkware. Lontoo: Minnesota University Press.

Bateson, G. (1972) Steps to an ecology of mind. New York: Ballantine Books.

Bauman, Z. (2011) Collateral damage: Social inequalities in a global age. Malden: Polity Press.

Cameron, D. (1995) Verbal hygiene. Lontoo: Routledge.

Castells, M. (2010) The rise of the network society. 2. painos. Oxford: Wiley \& Blackwell.

Cooper, C. L. (2002) The changing psychological contract at work. Occupational \& Environmental Medicine 59 (6), 355. https://doi.org/10.1136/oem.59.6.355

Coyle-Shapiro, J. A.-M. \& Parzefall, M. (2008) Psychological contracts. Teoksessa C. L. Cooper \& J. Barling (toim.) The SAGE handbook of organizational behavior. Lontoo: Sage, 17-34.

De Hauw, S. \& De Vos, A. (2010) Millennials' career perspective and psychological contract expectations: Does the recession lead to lowered expectations? Journal of Business and Psychology 25 (2), 293-302. https://doi.org/10.1007/s10869010-9162-9

Deleuze, G. (1995) Negotiations, 1972-1990. New York: Columbia University Press.

Deleuze, G. (2006) May '68 didn't happen. Teoksessa D. Lapoujade (toim.) Two regimes of madness: Texts and interviews 1975-1995. New York: Semiotext(e), 233-236.

Deleuze, G. \& Guattari, F. (1972) L'anti-Oedipe: Capitalisme et schizophrenie. Pariisi: Minuit.

Deleuze, G. \& Guattari, F. (1980) Mille plateaux. Pariisi: Minuit.

Deleuze, G. \& Guattari, F. (1991) Qu'est-ce que la philosophie? Pariisi: Minuit.

Ehrenreich, B. (2006) Petetty keskiluokka. Tampere: Vastapaino.

Eräsaari, L. (2002) Julkinen tila ja valtion yhtiöittäminen. Helsinki: Gaudeamus. 
Eräsaari, L. (2015) Miten uusliberalistinen hegemonia rakennettiin Suomeen? Tieteessä tapahtuu 33 (3), 63-66.

Flecker, J. \& Hofbauer, J. (1998) Capitalising on subjectivity: The 'new model worker' and the importance of being useful. Teoksessa P. Thompson \& C. Warhurst (toim.) Workplaces of the future. Houndmills: Palgrave, 104-123.

Glynn, S. (2020) The economic logic of late capitalism and the inevitable triumph of socialism. Lontoo: Palgrave Macmillan.

Graeber, D. (2018) Bullshit jobs: A theory. Lontoo: Allen Lane.

Halmetoja, A. (2016) Universalismi sosiaalipolitiikan ideaalina. Teoksessa A. Halmetoja, P. Koistinen \& S. Ojala (toim.) Sosiaalipolitiikan lumo. Tampere: Tampere University Press, 119-128.

Heikkilä, T. (1998) Muutosmyrsky: Pankkifuusio työntekijöiden kokemuksena. Espoo: Teknillinen korkeakoulu.

Heiskala, R. (2003) Society as semiosis: Neostructuralist theory of culture and society. New York: Peter Lang.

Heiskala, R. \& Kantola, A. (2010) Vallan uudet ideat: Hyvinvointivaltion huomasta valmentajavaltion valvontaan. Teoksessa P. Pietikäinen (toim.) Valta Suomessa. Helsinki: Gaudeamus, 124-148.

Herriot, P. (1992) The career management challenge: Balancing individual and organisational needs. Lontoo: Sage.

Hertzen, M. von (2010) Luovien läpi suhdanteiden: SEFE Suomen Ekonomiliitto 75 vuotta. Helsinki: SEFE Suomen Ekonomiliitto.

Hodson, R. (2001) Dignity at work. Cambridge: Cambridge University Press.

Häyry, M. (2020) Koronasolidaarisuuden kahdet kasvot. Etiikka-verkkolehti. https://etiikka.fi/koronasolidaarisuuden-kahdet-kasvot/ (luettu 24.8.2020)

Ilmakunnas, P. \& Maliranta, M. (2000) Työpaikkojen ja työntekijöiden vaihtuvuus laman ja elpymisen aikana. Kansantaloudellinen aikakauskirja 96 (2), 233-248.

Jakonen, M. (2015) Let's kill the messenger! The reception and recognition of the precarity movement and argument in Finland. Teoksessa D. della Porta, T. Silvasti, S. Hänninen \& M. Siisiäinen (toim.) The new social division: Making and unmaking precariousness. Houndmills: Palgrave Macmillan, 177-196.

Julkunen, R. (2001) Suunnanmuutos: 1990-luvun sosiaalipoliittinen reformi Suomessa. Tampere: Vastapaino. 
Julkunen, R. (2008) Uuden työn paradoksit: Keskusteluja 2000-luvun työpross(e)ista. Tampere: Vastapaino.

Kalela, J. (1989) Työttömyys 1900-luvun suomalaisessa yhteiskuntapolitiikassa. Helsinki: Valtion painatuskeskus.

Kantola, A. (2002) Markkinakuri ja managerivalta: Poliittinen hallinta Suomen 1990-luvun talouskriisissä. Helsinki: Loki-kirjat.

Kettunen, P. (2002) Suunnitelmataloudesta kansalliseen innovaatiojärjestelmään. Teoksessa H. Blomberg, M. Hannikainen \& P. Kettunen (toim.) Lamakirja: Näkökulmia 1990-luvun talouskriisiin ja sen historiallisiin konteksteihin. Turku: Kirja-Aurora, 15-45.

Kiander, J. (2002) 1930-luvun pulakausi ja 1990-luvun talouskriisi. Teoksessa H. Blomberg, M. Hannikainen \& P. Kettunen (toim.) Lamakirja: Näkökulmia 1990-luvun talouskriisiin ja sen historiallisiin konteksteihin. Turku: KirjaAurora, 47-70.

Kiander, J. \& Vartia, P. (1998) Suuri lama: Suomen 1990-luvun kriisi ja talouspoliittinen keskustelu. Helsinki: ETLA.

Koistinen, P. (2014) Työ, työvoima ja politiikka. Tampere: Vastapaino.

Kortteinen, M. \& Tuomikoski, H. (1998) Työtön: Tutkimus pitkäaikaistyöttömien selviytymisestä. Helsinki: Tammi.

Kuivalainen, S. (2010) Kestääkö suomalainen vähimmäisturva pohjoismaisen vertailun? Vertaileva analyysi vähimmäisturvan tasosta ja sen köyhyyttä ehkäisevästä vaikutuksesta neljässä Pohjoismaassa 1990-2005. Yhteiskuntapolitiikka 75 (4), 377-388.

Lamponen, H. (2019) Itsensätyöllistäjien oikeudesta työehtosopimustoimintaan - edellytykset ja rajoitukset. Teoksessa J. Paanetoja (toim.) Työoikeudellisen Yhdistyksen vuosikirja 2018. Helsinki: Työoikeudellinen Yhdistys, 61-96.

Lazzarato, M. (2012) The making of the indebted man: An essay on the neoliberal condition. Amsterdam: Semiotext(e).

Lazzarato, M. (2014) Immaterial labor. Teoksessa A. Pendakis ym. (toim.) Contemporary Marxist theory: A reader. New York: Bloomsbury, 77-91.

Levinson, H., Price, C. R., Munden, K. J., Mandl, H. J. \& Solley, C. M. (1962) Men, management, and mental health. Boston: Harvard University Press.

Levä, I. (2019) Työttömyyskassojen edelläkävijä: IAET-kassa 1969-2019. Helsinki: KOKO-kassa. 
Levä, I. (2021, tulossa) Toimihenkilöt neuvottelupöydässä: Järjestöt työmarkkinoiden taitekohdissa 1945-2015. Helsinki: Gaudeamus.

Lotman, Y. (1990) Universe of the mind: A semiotic theory of culture. Bloomington \& Indianapolis: Indiana University Press.

Luthar, S., Cicchetti, D. \& Becker, B. (2000) The construct of resilience: A critical evaluation and guidelines for future work. Child Development 71 (3), 543-562.

Maczulskij, T. (2016) Ketkä jäävät työttömyyskassojen ulkopuolelle? Työpapereita - Working Papers 304. Helsinki: Palkansaajien tutkimuslaitos.

Maczulskij, T. (2018) Pakollinen työttömyysvakuutus auttaisi heikompiosaisia. https://www.stn-wip.fi/en/2018/03/pakollinen-tyottomyysvakuutus-auttaisiheikompiosaisia/ luettu (1.10.2020)

Mannevuo, M. (2015) Affektitehdas: Työn rationalisoinnin historiallisia jatkumoita. Turku: Turun yliopisto.

Matalapalkkatyö Suomessa (2013) Valtioneuvoston kanslian raporttisarja 1/2013. Helsinki: Valtioneuvoston kanslia.

Mustakallio, P. (2003) Kannustin- ja velvoitelinja: Sosiaalipolitiikan hegemoninen projekti vuosituhannen vaihteen Suomessa. Pro gradu -tutkielma. Sosiaalipolitiikka, Tampereen yliopisto.

Niiniluoto, I. (1994) Suomen henkinen tila ja tulevaisuus. Teoksessa I. Niiniluoto \& P. Löppönen (toim.) Suomen henkinen tila ja tulevaisuus. Helsinki: WSOY, $13-46$.

Ojala, S. (2016) Työttömyyden sanktioinnin sijaan aktiivisuuslisää yhteiskunnallisesta työstä. Teoksessa A. Halmetoja, P. Koistinen \& S. Ojala (toim.) Sosiaalipolitiikan lumo. Tampere: Tampere University Press, 102-115.

Ojala, S. (2017) Älä niele työelämäväittämiä purematta. Meteli-verkkolehti. https://www.teme.fi/fi/meteli/ala-niele-tyoelamavaittamia-purematta/ (luettu 12.3.2020)

Outinen, S. (2015) Sosiaalidemokraattien tie talouden ohjailusta markkinareaktioiden ennakointiin: Työllisyys sosiaalidemokraattien politiikassa Suomessa 1975-1998. Helsinki: Into Kustannus.

Paavola, J.-M., Pitkänen, S., Vainio, A., Valtakari, M. \& Ylikoski, M. (2019) Matalapalkkatyön yleistyminen ja suomalainen sosiaaliturva - Muutoksen vaikutukset kansainvälisen kokemuksen valossa. Valtioneuvoston selvitys- ja tutkimustoiminnan julkaisusarja 2019:39. Helsinki: Valtioneuvoston kanslia. 
Rentola, K. (2005) Vallankumouksen aave: Vasemmisto, Beljakov ja Kekkonen 1970. Helsinki: Otava.

Reunanen, E. \& Väliverronen, J. (2020) Tupo ja media: Talous- ja työmarkkinapoliittisen julkisuuden toimintahorisontit kolmella vuosikymmenellä. Tampere: Tampere University Press.

Rifkin, J. (2000) The age of access. New York: Putnam.

Rodríguez-Giralt, I., Tirado, F. \& Tironi, M. (2014) Disasters as meshwork: Migratory birds and the enlivening of Doñana's toxic spill. The Sociological Review 62 (1), 38-60. https://doi.org/10.1111/1467-954X.12123

Ronkainen, J. \& Punamäki, M. (toim.) (2013) Nuoret ja syrjäytyminen Itä-Suomessa. Tutkimuksia ja raportteja 78. Mikkeli: Mikkelin ammattikorkeakoulu.

Rousseau, D. M. (1989) Psychological and implied contracts in organizations. Employee Responsibilities and Rights Journal 2 (2), 121-139.

Räisänen, H. (2020) Hystereesi on pidettävä kurissa. Työpoliittinen aikakauskirja $63(2), 7-8$.

Saari, T. (2014) Psykologiset sopimukset ja organisaatioon sitoutuminen tietotyössä. Tampere: Tampere University Press.

Salo, U.-M. (2015) Simsalabim, sisällönanalyysi ja koodaamisen haasteet. Teoksessa S. Aaltonen \& R. Högbacka (toim.) Umpikujasta oivallukseen: Refleksiivisyys empiirisessä tutkimuksessa. Tampere: Tampere University Press, $166-190$.

Salovaara, P. (2020) Johtopäätös: Yhteisöt ja organisaatiot pomokulttuurin jälkeen. Helsinki: Teos.

Sarkki, S., Balian, E., Heink., U., Keune, H., Nesshöver, C., Niemelä, J., Tinch, R., Van Den Hove, S., Watt, A., Waylen, K. A. \& Young, J. C. (2020) Managing science-policy interfaces for impact: Interactions within the environmental governance meshwork. Environmental Science and Policy 23 (113), 21-30. https://doi.org/10.1016/j.envsci.2019.05.011

Schein, E. H. (1965) Organizational psychology. Englewood Cliffs: Prentice Hall. Sennett, R. (2002) Työn uusi järjestys: Miten uusi kapitalismi kuluttaa ihmisen luonnetta. Tampere: Vastapaino.

Siltala, J. (1994) Miehen kunnia: Modernin miehen taistelu häpeää vastaan. Helsinki: Otava. 
Siltala, J. (2004) Työelämän huonontumisen lyhyt historia: Muutokset hyvinvointivaltioiden ajasta globaaliin hyperkilpailuun. Helsinki: Otava.

Siltala, J. (2017) Keskiluokan nousu, lasku ja pelot. Helsinki: Otava.

Silvennoinen, H., Kalalahti, M. \& Varjo, M. (2018) Koulutususko

yhteiskunnallisena ilmiönä. Teoksessa H. Silvennoinen, M. Kalalahti \& J. Varjo

(toim.) Koulutuksen lupaukset ja koulutususko. Kasvatussosiologian

vuosikirja 2. Kasvatusalan tutkimuksia 79. Helsinki: Suomen kasvatustieteellinen seura, 11-40.

Sitra (2004) Artikkelikokoelma tutkimushankkeesta Sosiaaliset innovaatiot, yhteiskunnan uudistumiskyky ja taloudellinen menestys. Helsinki: Sitra.

Sloterdijk, P. (2013) Nietzsche apostle. Los Angeles: Semiotext(e).

Smithson, J. \& Lewis, S. (2000) Is job insecurity changing the psychological contract? Personnel Review 29 (6), 680-702. https://psycnet.apa.org/ doi/10.1108/00483480010296465

Stiegler, B. (2010) Technics and time, 3: Cinematic time and the question of malaise. Stanford: Stanford University Press.

Stiegler, B. (2015) La Société automatique: 1. L'avenir du travail. Pariisi: Fayard.

Suhonen, S. (2020) Z-sukupolven työelämäodotukset. Opinnäytetyö. Satakunnan ammattikorkeakoulu.

Suoranta, A. (2009) Halvennettu työ: Pätkätyö ja sukupuoli sopimusyhteiskuntaa edeltävissä työmarkkinakäytännöissä. Tampere: Vastapaino.

Timonen, V. (2002) Intressit ja hyvinvointivaltion puolustus: Ay-liike työttömyysturvan leikkauksien vastustajana. Teoksessa H. Blomberg, M. Hannikainen \& P. Kettunen (toim.) Lamakirja: Näkökulmia 1990-luvun talouskriisiin ja sen historiallisiin konteksteihin. Turku: Kirja-Aurora, $255-280$.

Turtiainen, J., Anttila, E. \& Väänänen, A. (2020) Social work, emotion management and the transformation of the welfare state. Journal of Social Work. https://doi.org/10.1177/1468017320973586

Varela, F. J. (1991) Organism: A meshwork of selfless selves. Teoksessa A. I. Tauber (toim.) Organism and the origins of self. Dordrecht: Springer, 79-107.

Varje, P. (2018) Cracks in the mirror: The ideal worker and the labor process in Finnish working life after the second world war. Helsinki: Unigrafia. 
Virtanen, A. (2006) Biopoliittisen talouden kritiikki. Helsinki: HSE \& Tutkijaliitto.

Vähämäki, J. (2003) Kuhnurien kerho: Vanhan työn paheista uuden hyveiksi. Helsinki: Tutkijaliitto.

Vähätalo, K. (1983) Työtön ja yhteiskunta: Tutkimus työttömyyden vaikutuksista työttömiin ja yhteiskuntaan. Työvoimapoliittisia tutkimuksia n:o 146. Helsinki: Työvoimaministeriö.

Yliaska, V. (2015) Tehokkuuden toiveuni: Uuden julkisjohtamisen historia Suomessa 1970-luvulta 1990-luvulle. Helsinki: Into Kustannus. 


\section{Ilkka Levä}

The war within Finland? A Deleuzian analysis of the societal production of the new psychological contract in the press during the 1990s recession

The change of the psychological contract (PC) of work in 1990s Finland is studied by applying the theories of Deleuze and Guattari. The study illustrates the change in the hegemonic frames of public discourse and its order words in Finnish newspapers regarding the body of working life during the recession of the 1990s. It altered working life: the new leading theme was efficiency and its improvement. New order words led to the new cultural reading of the psychological contract of work. It was depicted as an on-going battle in a war. The change in the agreement continues to have an impact, as it is being continuously renegotiated through arbitrary pressures towards working bodies in the metastable unstableness of the current biopolitical economy. 